\title{
Purification and Characterization of Thermo Stable DNase of Staphylococcus Aureus Isolated from Different Clinical Source
}

\author{
Noor Naeem Khwen ${ }^{1}$, Sawsan Hassan Authman ${ }^{2}$, Mohammed Faraj AL- Marjani ${ }^{2}$ \\ ${ }^{1}$ Ass. Lecturer, Al-Rafidain University College, Baghdad, Iraq, ${ }^{2}$ Prof., Department of Biology, \\ College of Science, Al-Mustansiriyah University, Baghdad, Iraq
}

\begin{abstract}
Hundred samples were collected from different clinical source. Sixty isolates were identified as Staphylococcus aureus. The ability of $S$. aureus to produce DNase was examined phenotypically on DNase agar medium and also by quantitative assay that revealed only $37(66 \%)$ of $S$. aureus were able to produce the enzyme. DNase was extracted, the crude activity and specific activity was $38(\mathrm{U} / \mathrm{ml})$ and $253.3(\mathrm{U} / \mathrm{mg})$ respectively. The enzyme purified by precipitating with ammonium sulphate at (65-85\%) saturation then by using ion exchange chromatography in CM cellulose and gel filtration by using Sephadex G150. Purified DNase activity and specific activity was $42(\mathrm{U} / \mathrm{ml})$ and $4200(\mathrm{U} / \mathrm{mg})$ respectively. The optimum PH for DNase was found to be 8 while the enzyme was stable at wide range of $\mathrm{pH}(8,9$ and 10) with remaining activity $100 \%, 90 \%, 86 \%$ respectively. The optimum temperature for DNase was $37^{\circ} \mathrm{C}$ while the stability was also at $37^{\circ} \mathrm{C}$. Results indicate that DNase activity increased when the enzyme was incubated with $10 \mathrm{mM}$ of each $\mathrm{MnCl}_{2}, \mathrm{KCl}, \mathrm{NaCl}, \mathrm{MgCl}_{2}$, and $\mathrm{CaCl}_{2}$. The molecular weight of DNase was done by gel filtration and found to be approximately 19KDa.
\end{abstract}

Keywords: Purification, thermo stable DNase, Staphylococcus aureus.

\section{Introduction}

Staphylococcus aureus is a Gram-positive bacterium living as a commensal on the skin, mouth and upper respiratory system, making it a risk factor for opportunistic and nosocomial infections (1). This group of microorganisms has various virulence factors subscribe to the ability of $S$. aureus to cause infection enzymes, cell-surface proteins, toxins, factors that assistance in avoiding the innate immune defense ${ }^{(2)}$. One of the distinguishing characteristics of $S$. aureus is its ability to produce a wide variety of exoenzymes ${ }^{(3)}$.

Among these exoenzymes, nuclease (EC 3.1.31.1) which was originally identified in 1956 by Cunningham and was named such as micrococcal nuclease, thermonuclease, deoxyribonuclease and DNase, and hereafter we will refer to the enzyme as DNase due to its ease of purification ${ }^{(4,5)}$.

Nucleases are very important enzymes belonging to the group of hydrolases that degrade nucleic acids (6). Staphylococcal nuclease catalyzes the hydrolysis of both DNA and RNA at the 5' position of the phosphodiester bond yielding a free 5'-hydroxyl group and a 3'-phosphate monoester. The $\mathrm{pH}$ optimum is between 8.6 and 10.3 and varies inversely with $\mathrm{Ca} 2+$ concentration, but at any $\mathrm{pH}$ rather high levels of $\mathrm{Ca}$, typically

\section{1 $\mathrm{M}$, are required for optimal activity ${ }^{(7)}$.}

A remarkable tolerance to prolonged heating and storage is exhibited by staphylococcal nuclease in foods and broth, and its presence is closely related with the occurrence of enterotoxins in food poisoning outbreaks ${ }^{(8)}$. The gene encoding for staphylococcal nuclease (nuc) has also been widely used as a specific marker for the detection of $\mathrm{S}$. aureus in various types of food and clinical samples ${ }^{(9,10)}$.

\section{Materials and Method}

Isolation of bacteria: From 100 samples of different clinical sources (60) isolates primary diagnosed as $S$. aureus depending on cultural morphological and biochemical test. These characteristics include; colonial morphology, size of colony, ability to ferment mannitol. Bacterial isolates were examined and identified by 
microscopic, biochemical test and Vitek2 system characteristics ${ }^{(11)}$.

Phenotypic detection of thermo stable DNase: Sixty isolates of $S$. aureus and were cultured by streaking on DNase agar and incubate at $35^{\circ} \mathrm{C}$ for $18-24 \mathrm{hr} .{ }^{(12,13)}$

The quantitative assay thermo stable DNase: All $S$. aureus isolates were cultured in nutrient broth overnight in a concentration comparable to McFarland standard no. 0.5. Afterward, then centrifuged at $8000 \times \mathrm{g}$ for $15 \mathrm{~min}$. The supernatant was taken, boiled for 15 min and cooled down at $4{ }^{\circ} \mathrm{C}$. Afterward, $50 \mu 1$ of supernatant was poured in wells punched in DNase agar and incubated overnight. A zone of pink or rose color around the well indicated a positive result; which were measured by an aid of metric ruler ${ }^{(14)}$.

Extraction thermo stable DNase: The method described by Ohsaka et al. (15) was followed with some modifications for the purification of DNase. The isolate; which developed the largest zone of clearance on DNase agar, was cultured in $100 \mathrm{ml}$ of nutrient broth at $32{ }^{\circ} \mathrm{C}$ for $24 \mathrm{hr}$. on a rotary shaker at $100 \mathrm{rpm}$. Subsequently, supernatant was obtained, heated in boiling water for $15 \mathrm{~min}$ then cooled.

Purification of thermo stable DNase: The crude DNase was subjected to different steps of purification including ammonium sulphate $\left(\mathrm{NH}_{4}\right)_{2} \mathrm{SO}_{4}$ precipitation, dialysis, CM- cellulose ion-exchange chromatography and gel filtration by using gradient elution buffer.

Thermo stable DNase Assay: Pseudomonas aeruginosa DNA was extracted by Presto ${ }^{\mathrm{TM}}$ Mini gDNA Bacteria Kit (Geneaid Corporation $\backslash$ Korea). A volume of $2.5 \mu 1$ of the sample was incubated with $7.5 \mu 1$ E. coli DNA $(1 \mathrm{mg} / \mathrm{ml})$ and $40 \mu 1$ DNase buffer (0.01 M CaCl2, $0.1 \mathrm{M}$ Tris $\mathrm{HCl}$; $\mathrm{pH}$ 8) for $60 \mathrm{~min}$ at $37^{\circ} \mathrm{C}$. The nuclease reaction was stopped with 12.5 $\mu 1$ of 0.33 M EDTA (pH 8.0). One unit of activity was expressed as change in absorbance at $260 \mathrm{~nm}^{(15,16)}$.

\section{Characterization of thermo stable DNase}

Determination of optimum pH for DNase activity and stability: The effect of $\mathrm{pH}$ on the purified DNase activity was done by adding the enzyme solution $(0.1$ $\mathrm{ml})$ to one $\mathrm{ml}$ of $(0.1 \mathrm{M})$ Tris-HCl buffer at different $\mathrm{pH}$ values (5 to 11) and the activity was determined by performing the standard assay procedure. While the $\mathrm{pH}$ effect on DNase stability was done using Equal volumes of purified enzyme solution was reacted with different $\mathrm{pH}$ buffers range from (5 to 11) was incubated at a room temperature for $30 \mathrm{~min}$. The enzymatic activity for each one was measured ${ }^{(17)}$.

Determination of optimum temperature for DNase activity and stability: The DNase activity was measured at different temperatures $(20,37,40,60,80$ and $100{ }^{\circ} \mathrm{C}$ ). The remaining activity was plotted against the temperature. While for thermal stability, equal volumes of purified alkaline phosphatase was incubated in water bath at $\left(30,40,50,60,70,80,90\right.$, and $\left.100^{\circ} \mathrm{C}\right)$ for $30 \mathrm{~min}$., and immediately transferred into an ice bath. Enzymatic activity was measured and the remaining activity (\%) was plotted against the temperature ${ }^{(17)}$.

Determination of various metal ions effects on DNase activity: The enzyme was incubated with an equal volume of different metal ions $\mathrm{MnCl}_{2}, \mathrm{KCl}, \mathrm{NaCl}$ $\mathrm{MgCl}_{2}$ and $\mathrm{CaCl}_{2}$ at a concentration of $10 \mathrm{mM} / \mathrm{mL}$ at 37 ${ }^{\circ} \mathrm{C}$ for 30 minutes. The enzyme activity was assayed for each treatment. The control was the enzyme solution without any of these compounds. The remaining activity was assayed for each treatment.

Molecular weight determination for DNase: Molecular weight was determined by gel filtration technique using the column Sephadex G-150 with dimensions $1.5 \times 80 \mathrm{~cm}$. The column was calibrated with Lysozyme $(14 \mathrm{KDa})$, carbonic anhydrase $(29,000)$, albumin (66 KDa) and alcohol dehydrogenase $(150,000)$. Dextran blue $(2,000,000)$ was used to determine the void volume ${ }^{(18)}$.

\section{Results and Discussion}

Isolation and Identification of taphylococcus aureus: From 100 samples from different clinical sources 60 isolates were primary diagnosing as $S$. aureus depending on biochemical, morphological and cultural characteristics. These samples were collected from different sources such as wound, urine, burn, wound, blood, stool, and sputum and nose table 1 . These samples were collected from many hospitals in Baghdad. .All colonies from primary culture were purified by subculture on blood agar and then re inoculated on Mannitol Salt Agar at $37^{\circ} \mathrm{C}$ for $24 \mathrm{hr}{ }^{(19)}$. 
Table 1: Percentage of Staph aureus with difference Source infection

\begin{tabular}{|l|c|c|}
\hline $\begin{array}{l}\text { Sources of } \\
\text { isolation }\end{array}$ & $\begin{array}{c}\text { Number of } \\
\text { samples }\end{array}$ & $\begin{array}{c}\text { S.aureus } \\
\text { Percentages \% }\end{array}$ \\
\hline Urine & 20 & 33 \\
\hline Burns & 10 & 17 \\
\hline Wounds & 9 & 15 \\
\hline Blood & 8 & 13 \\
\hline Stool & 7 & 12 \\
\hline Sputum & 3 & 5 \\
\hline Nose & 3 & 5 \\
\hline
\end{tabular}

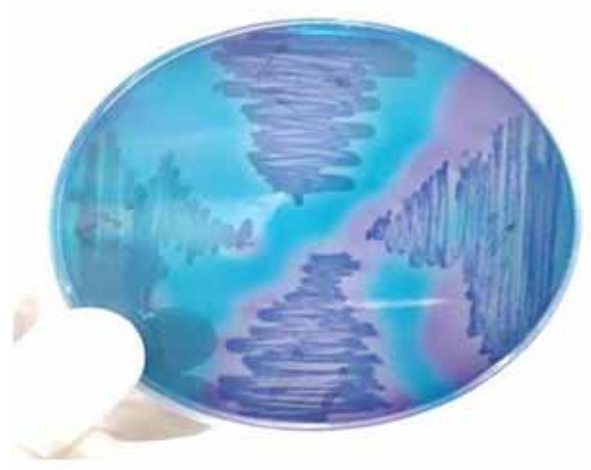

A
Phenotypic detection of thermo stable DNase: Sixty isolates of $S$. aureus isolates were cultured by streaking on DNase agar. Results showed that 56(93\%) of $S$. aureus isolates gave positive result on DNase agar by changing the color from blue to pink or rose color while only 4 (7\%) of $S$. aureus were non producer figure 1.

The quantitative assay thermo stable nuclease: The quantitative assay was done for fifty six isolates of S. aureus. Result revealed that only $37(66 \%)$ of $S$. aureus were able to produce thermo stable nuclease while $19(34 \%)$ were non producer. Staphylococcus aureus 43 was chosen for DNase extraction since that it accomplished the highest zone of clearance on DNase agar figure 1 .

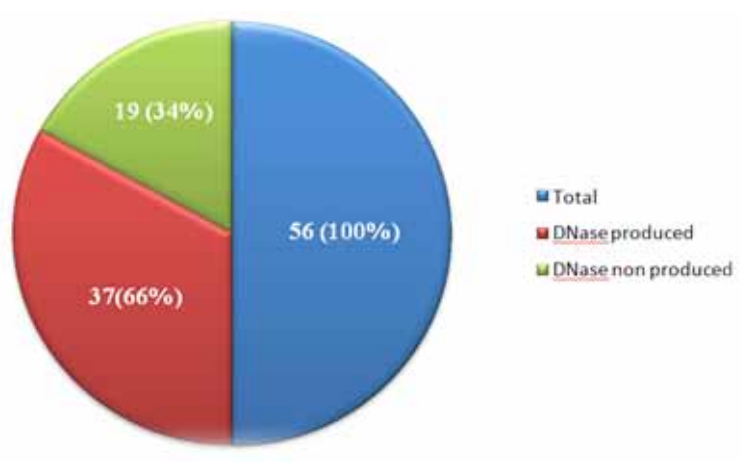

B

Figure 1: A-Screening of $S$. aureus DNase production; B- Percent of thermo stable DNase production by Staphylococcus aureus

Extraction of the enzyme: Supernatant of this S. aureus $43 \mathrm{c}$ was boiled to achieve the inhibition of other enzymes activities and remaining bacterial cell. Tang et al.,(20) indicated that the nucleases secreted by strains still showed functional activity after $30 \mathrm{~min}$ at $121^{\circ} \mathrm{C}$. The crude DNase activity and specific activity was $38 \mathrm{U} / \mathrm{ml}$ and $253.3 \mathrm{U} / \mathrm{mg}$ respectively.

Purification of the enzyme: After extraction, the supernatant was taken for (65-85\%) ammonium sulphate precipitation. The DNase activity and specific activity was $(31 \mathrm{U} / \mathrm{ml})$ and $(606 \mathrm{U} / \mathrm{mg})$ protein respectively. The sample was subjected to $\mathrm{CM}$ cellulose column by linear gradient of $\mathrm{NaCl}(0.1-1 \mathrm{M})$. The results showed four peaks in wash step, only the first peak of them showed DNase activity $(29 \mathrm{U} / \mathrm{ml})$ in fraction numbered 22 to 27 while the last three peaks had no DNase activity thus it was neglected. The fifth protein peak with $0.3 \mathrm{M}$ of $\mathrm{NaCl}$ at fraction numbered 71 to 78 showed the highest DNase activity reached to $49 \mathrm{U} / \mathrm{ml}$ figure 2. Ibraheem and Al-Mathkhury., (16) reported that the specific activity of DNase extracted from Staphylococcus aureus was $241.920 \mathrm{U} / \mathrm{mg}$.

Further purification carried out by a gel filtration using Sephadex G150. Enzymic fractions from CMcellulose were pooled and passed through gel filtration column. The fractionation yielded one protein peaks as absorbance reading at $280 \mathrm{~nm}$. DNase activity was (42U/ $\mathrm{ml})$, protein concentration $(0.01 \mathrm{mg} / \mathrm{ml})$ with specific activity $(4200 \mathrm{U} / \mathrm{mg})$ and the purification fold was (16.5) with yield of enzyme (46.4\%) as mentioned in figure 2 and table 2 . 


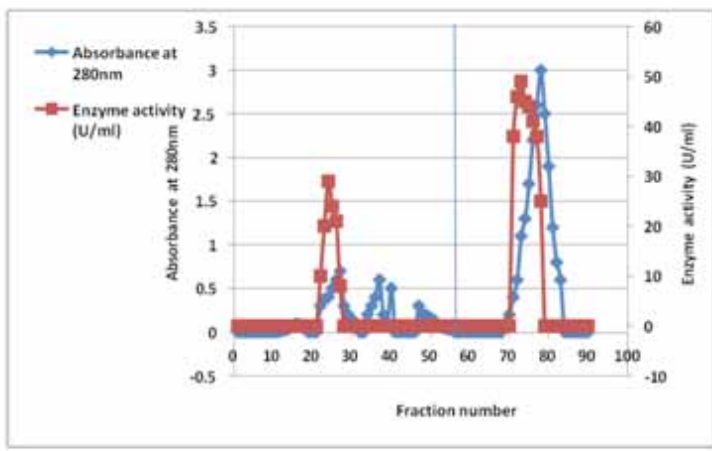

A

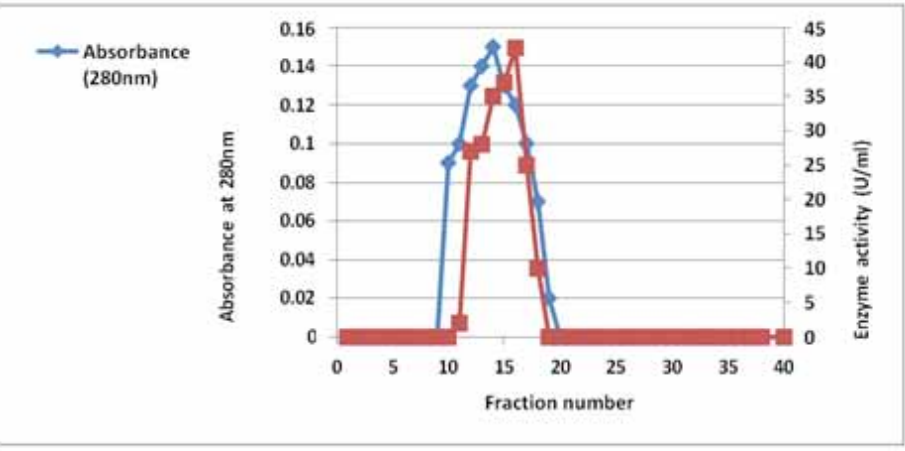

B

Figure 2: A- Ion exchange chromatography of DNase produced by using CM-cellulose column $(2 \times 20 \mathrm{~cm})$.

The flow rate was a drop per 5 seconds, $3 \mathrm{ml}$ per tube; temperature, $10{ }^{\circ} \mathrm{C}$; B- Gel filtration chromatography for purified DNase from St. aureus by using Sepharose-6B column $(1.5 \times 80) \mathrm{cm}$. The column was calibrated with $0.1 \mathrm{M}$ Tris-HCl $\mathrm{pH} 8$.

Table 2: Purification steps of DNase from staphylococcus aureus

\begin{tabular}{|c|c|c|c|c|c|c|c|}
\hline Purification step & $\begin{array}{l}\text { Volume } \\
\text { (ml) }\end{array}$ & $\begin{array}{c}\text { Enzyme } \\
\text { activity (U/ } \\
\text { ml) }\end{array}$ & $\begin{array}{c}\text { Protein } \\
\text { Concentration } \\
(\mathrm{mg} / \mathrm{ml})\end{array}$ & $\begin{array}{c}\text { Specific } \\
\text { activity (U/mg } \\
\text { protein) }\end{array}$ & $\begin{array}{c}\text { Total } \\
\text { activity } \\
\text { (U) }\end{array}$ & $\begin{array}{l}\text { Purification } \\
\text { (folds) }\end{array}$ & $\begin{array}{l}\text { Yield } \\
(\%)\end{array}$ \\
\hline Crude enzyme & 50 & 38 & 0.15 & 253.3 & 1900 & 1 & 100 \\
\hline $\begin{array}{l}\text { Ammonium sulfate } \\
\text { precipitation }(65-85 \%)\end{array}$ & 50 & 31 & 0.05 & 606 & 1550 & 2.3 & 80.4 \\
\hline Dialysis & 40 & 32 & 0.02 & 1600 & 1280 & 6.2 & 66.3 \\
\hline $\begin{array}{l}\text { Ion exchange chromatography } \\
\text { on DEAE-cellulose Wash }\end{array}$ & 18 & 29 & 0.02 & 1450 & 522 & 5.6 & 27 \\
\hline $\begin{array}{l}\text { Gel filtration chromatography } \\
\text { Sephadex G-150 }\end{array}$ & 21 & 42 & 0.01 & 4200 & 882 & 16.5 & 46.4 \\
\hline
\end{tabular}

\section{Characterization of thermo stable DNase:}

Determination of optimum pH for DNase activity and stability: The optimal $\mathrm{pH}$ for $S$. aureus DNase activity was found to be at $\mathrm{pH}=8$. However, DNase of $S$. aureus was still active over a wide range (6 to 9) of $\mathrm{pH}$ values. DNase activity decreased at $\mathrm{pH}(5,11$, and 12) figure $3 \mathrm{~A}$. Abdel-Gany, ${ }^{(21)}$ reported that the $\mathrm{pH}$ optima of DNase from human, pig, bovine, rabbit, rat and mouse were ranged from 6.5 to 7.0.

PH stability for DNase activity: The purified enzyme was incubated at different $\mathrm{pH}$ values for 30 min at $37^{\circ} \mathrm{C}$. DNase of S. aureus was stable in a wide range of $\mathrm{pH}(8,9$ and 10$)$ with remaining activity $100 \%$, $90 \%, 86 \%$ respectively figure $3 \mathrm{~B}$.

Effect of temperature on DNase activity: The effect of temperature on DNase activity was examined by performing the enzyme assay at various temperature ranging from $20^{\circ} \mathrm{C}$ to 100 , Purified DNase from S. aureus showed the highest activity at $37{ }^{\circ} \mathrm{C}$ with enzyme activity $(42 \mathrm{U} / \mathrm{ml}$ figure $3 \mathrm{C}$. Each enzyme has an optimum $\mathrm{pH}$ at which the rate of the reaction that it catalyzes is at its maximum. Small deviations in $\mathrm{pH}$ from the optimum value lead to decreasing the activity due to changes in the ionization of groups at the active site of the enzyme, while larger deviations in $\mathrm{pH}$ lead to the denaturation of the enzyme protein itself due to interference with many weak non covalent bonds, maintaining its three dimensional structure ${ }^{(22)}$.

Effect of temperature on DNase stability: Thermo stability of DNase was examined by pre incubation of pure enzyme in different temperatures $\left(30-100^{\circ} \mathrm{C}\right)$ for $30 \mathrm{mins}$ and then the remaining activity was determined after assaying enzyme activity.

The maximum stability of DNase was observed to be at 37 with remaining activity $100 \%$ figure $3 \mathrm{D}$. 
It has been reported that salt bridges play an important role in the high temperature tolerance of the protein. There are more salt bridges in thermophilic proteins ${ }^{(23)}$.

Effect of metal ions on DNase activity: Results in table 3 illustrate that DNase activity increased when

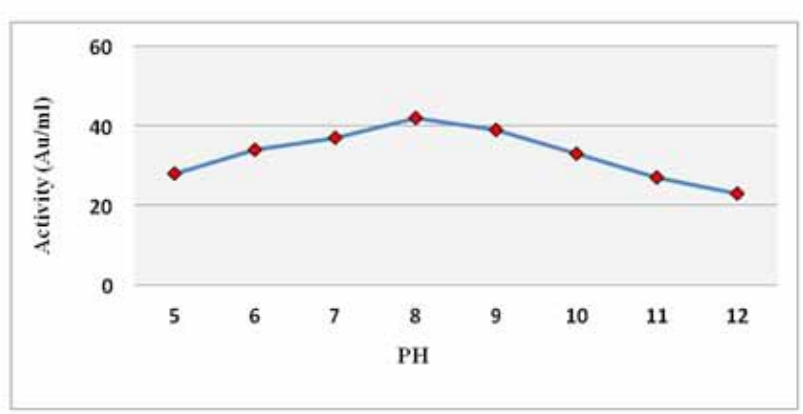

A

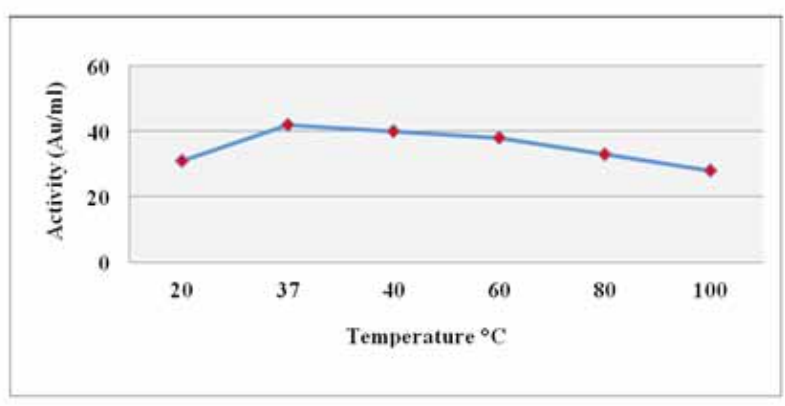

C the enzyme was incubated with $10 \mathrm{mM}$ of each $\mathrm{MnCl}_{2}$, $\mathrm{KCl}, \mathrm{NaCl}, \mathrm{MgCl}_{2}$, and $\mathrm{CaCl}_{2}$, which gave a higher enzyme activity. DNase I activity is 100 - fold lower in buffers that contain only one type of divalent cation compared to a $\mathrm{Ca}^{2+} / \mathrm{Mg}^{2+}$ reaction mixture, without any divalent cations, DNase I activity is almost negligible ${ }^{(24)}$.

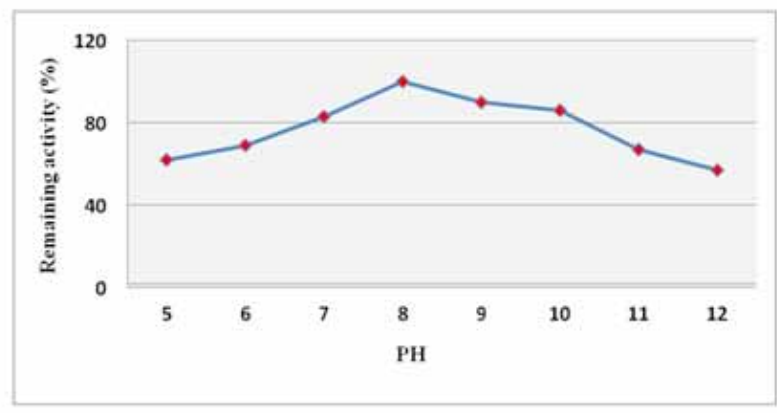

B

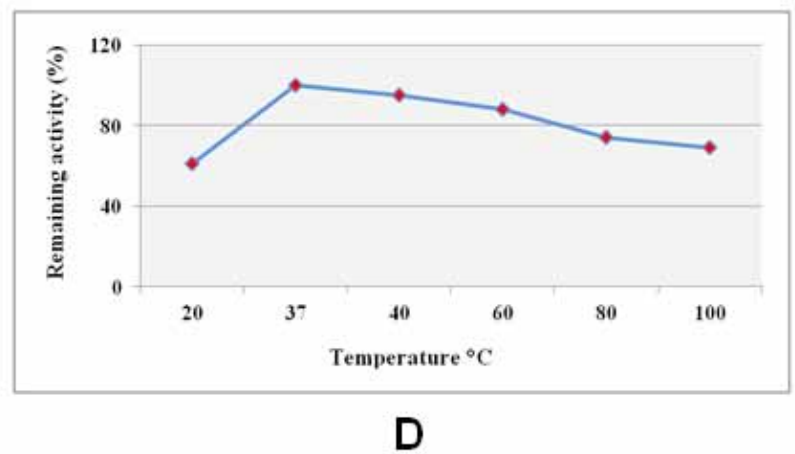

Figure 3: A- Effect of PH on Enzyme Activity; B- Effect of PH on Enzyme stability; C- Effect of Temperature on Enzyme Activity; D- Effect of Temperature on Enzyme stability

Table 3: Metal ions effect on DNase activity

\begin{tabular}{|l|c|}
\hline Metal ion & Remaining activity (\%) \\
\hline $\mathrm{MnCl}_{2}$ & 107 \\
\hline $\mathrm{KCl}$ & 112 \\
\hline $\mathrm{NaCl}$ & 119 \\
\hline $\mathrm{MgCl}_{2}$ & 126 \\
\hline $\mathrm{CaCl}_{2}$ & 129 \\
\hline
\end{tabular}

Determination of molecular weight for DNase: The molecular weight was estimated by gel filtration according to the logarithm molecular weight and elution volume/void volume ( $\mathrm{Ve} / \mathrm{Vo}$ ), the molecular weight for S. aureus DNase found to be $19 \mathrm{KDa}$. Ibraheem and Al-Mathkhury ${ }^{(16)}$ stated that the molecular weight of purified DNase extracted from Staphylococcus aureus was $16.8 \mathrm{kDa}$ by using SDS gel electrophoresis, while DNase purified from streptomyces by gel filtration was $19.9 \mathrm{kDa}^{(25)}$.

Ethic Statement: The researchers already have ethical clearance from all required institution and laboratories.

Source of Funding: Self fund.

Conflict of Interest: No conflict of interest

\section{References}

1. Gitau W, Masika M, Musyoki M, Museve B, Mutwiri T. Antimicrobial susceptibility pattern of Staphylococcus aureus isolates from clinical specimens at Kenyatta National Hospital. BMC 
research notes, 2018; 11(1), 226. doi: 10.1186/ s13104-018-3337-2

2. Zecconi A, Scali F. Staphylococcus aureus virulence factors in evasion from innate immune defenses in human and animal diseases. Immunology letters, 2013; 150(1-2), 12-22. https:// doi.org/10.1016/j.imlet.2013.01.004

3. Bronner S, Monteil0 H, Pr'evost G. Regulation of virulence determinants in Staphylococcus aureus: complexity and applications. FEMS Microbiology Reviews, 2004; 28: 183-200. https:// doi.org/10.1016/j.femsre.2003.09.003

4. Fuchs S, Cuatrecasas P, Anfinsen CB. An improved method for the purification of staphylococcal nuclease. Journal of Biological Chemistry, 1967; 242: 4768-4770.

5. Kiedrowski MR, Kavanaugh JS, Malone CL, Mootz JM, et al. Nuclease modulates biofilm formation in community-associated methicillinresistant Staphylococcus aureus. PloS one, 2011; 6(11): e26714.

6. Maciejewska N, Walkusz R, Olszewski M, Szymańska A. New nuclease from extremely psychrophilic microorganism Psychromonas ingrahamii 37: identification and characterization. Molecular Biotechnology, 2019; 61(2), 122-133. DOI: $10.1007 / \mathrm{s} 12033-018-0142-\mathrm{z}$

7. Dunn BM, DiBello C, Anfinsen CB. The $\mathrm{pH}$ Dependence of the Steady State Kinetic Parameters for Staphylococcal Nuclease-catalyzed Hydrolysis of Deoxythymidine- 3'-phosphate-5'p-nitrophenylphosphate in $\mathrm{H}_{2} \mathrm{O}$ and $\mathrm{D}_{2} \mathrm{O}$. Journal of Biological Chemistry, 1973; 248(13), 47694774.

8. Hu Y, Xie Y, Tang J, Shi X. Comparative expression analysis of two thermostable nuclease genes in Staphylococcus aureus. Foodborne Pathogens and Disease, 2012; 9(3), 265-271. DOI: 10.1089/fpd.2011.1033

9. Brakstad OG, Aasbakk K, Maeland JA. Detection of Staphylococcus aureus by polymerase chain reaction amplification of the nuc gene. Journal of clinical microbiology, 1992; 30(7): 1654-1660. doi: 10.1128/JCM.30.7.1654-1660.1992.

10. Alarcon B, Vicedo B, Aznar R. PCR-based procedures for detection and quantification of Staphylococcus aureus and their application in food. Journal of applied microbiology, 2006;
100(2): 352-364. https://doi.org/10.1111/j.13652672.2005.02768.x

11. Brook I, Foote PA. Isolation of methicillin resistant Staphylococcus aureus from the surface and core of tonsils in children. International Journal of Pediatric Otorhinolaryngology, 2006; 70(12): 2099-2102. doi.org/10.1016/j.ijporl.2006. 08.004

12. BBLô DNase Test Agar with Toluidine Blue L007373 ï Rev. 05 ï July 2006, https://legacy. bd.com/ds/technicalCenter/inserts/L007373(05) (0706).pdf

13. Binford CH. Pathology-The Doorway to the Understanding of Leprosy: Ward Burdick Award Address. American Journal of Clinical Pathology, 1969; 51(6): 681-698. https://doi.org/10.1093/ ajcp/51.6.681

14. Harley JP, Prescott LM. Laboratory Exercises in Microbiology. 7thed. McGraw-Hill Higher Education, New York. 2007.

15. Ohsaka A, Mukai J-I, Laskowski Sr. The Use of Purified Micrococcal Nuclease in Identifying the Nucleotide Terminus Bearing a Free 5'-Monophosphate. Journal of Biological Chemistry, 1964; 239(10): 3498-3504.

16. Ibraheem HT, Al-Mathkhury HJ. Staphylococcal nuclease removes Escherichia coli and Klebsiella pneumoniae previously adhered to uroepithelial cells. Iraqi Journal of Science, 2015; 56(1B): 367378.

17. Adinarayana K, Ellaiah P, Prasad DS. Purification and partial characterization of thermostable serine alkaline protease from a newly isolated Bacillus subtilis. AAPS Pharmscitech, 2003; 4(4):440-448. doi.org/10.1208/pt040456

18. Andrews P. Estimation of molecular size and molecular weights of biological compounds by gel filtration. Method of Biochemical Analysis, 2006; 18. https://doi.org/10.1002/9780470110362. ch1

19. Brooks GF, Carroll KC, Butel JS, Morse SA. Jawetz Melnick and Adelbergs Medical Microbiology. 24 $4^{\text {th }}$ ed. The McGraw-Hill Companies, Inc., New York: 2007; pp. 224-232.

20. Tang J, Zhou Z, Shi X, Kang M, Wang H, Chen H. Twothermostable nucleases coexisted in Staphylococcus aureus: evidence frommutagenesis and invitro expression. FEMS Microbiology 
Letters, 2007; 284: 176-183.

21. Abdel-Gany SS, El-Badry MO, Fahmy AS, Mohamed SA. Purification and characterization of deoxyribonuclease from small intestine of camel Camelus dromedarius. Journal of Genetic Engineering and Biotechnology, 2017; 15(2): 463467. doi: 10.1016/j.jgeb.2017.06.008

22. Hames D, Hooper N. BIOS Instant Notes in Biochemistry $4^{\text {th }}$ Ed. 2011. ISBN-13: 9780415608459

23. Ding H, Gao F, Liu D, Li Z, Xu X, et al. Significant Improvement of thermal stability of glucose 1- dehydrogenase by introducing disulfide bonds at the tetramer interface. Enzyme and Microbial technology, 2013; 53(6-7): 365-372.

24. Pan CQ, Uumer JS, Herzka A, Lazarus RA. Mutational analysis of human DNase I at the DNA binding interface: implications for DNA recognition, catalysis, and metal ion dependence. Protein Science, 1998; 7(3): 628-636.

25. Al-Biyati AI, Al-Jumaily FE, Ibrahim AM. Purification of DNase produced by local Streptomyces isolates. Iraqi Journal of Biotechnology, 2005; 4(1): 90-107. 